Ambiente \& Água - An Interdisciplinary Journal of Applied Science
ISSN 1980-993X - doi:10.4136/1980-993X
www.ambi-agua.net
E-mail: ambi-agua@agro.unitau.br

\title{
A comprehensive analysis of the current and future role of biofuels for transport in the European Union (EU)
}

\author{
doi: 10.4136/ambi-agua.1492 \\ Received: 25 Aug. 2014; Accepted: 27 Nov. 2014

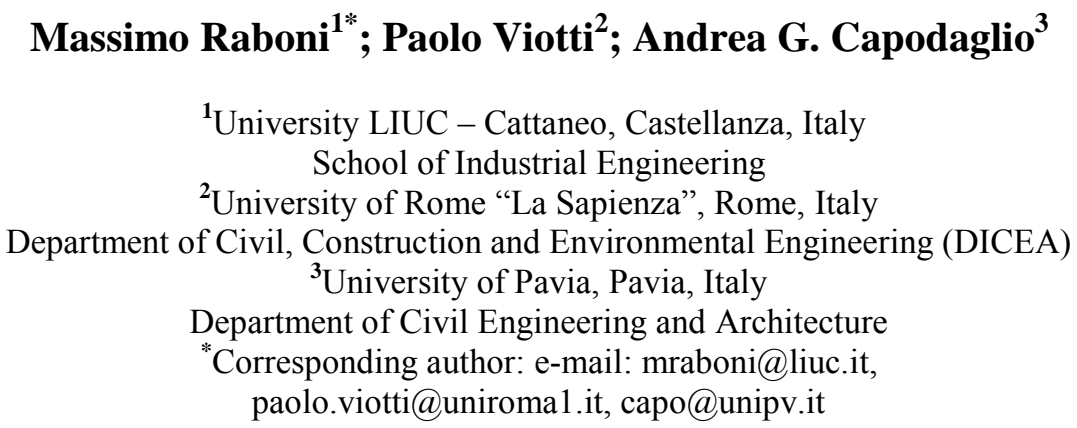

ABSTRACT

The production of biofuels is strongly supported all over the world as a renewable energy source for reducing dependence on the unstable oil market. Bioethanol, the main biofuel produced in the world, is widely used to power vehicles in both the USA and Brazil, but concerns exist in both places regarding its sustainability. In Brazil, it is produced from a by-product of the sugar cane industry, while in the USA it is manufactured from food crops. The production of biogas and biodiesel is growing rapidly, but neither has outpaced the production of bioethanol. The European Union (EU) is greatly interested in this issue, and in 2011 adopted an extensive strategy to reduce carbon dioxide emissions related to transport by $60 \%$ by the year 2050 . In order to achieve this result, the current European transportation system must be transformed. This ambitious goal will require the implementation of complex measures including the reduction of fossil fuels in favor of renewable fuels. This program has various options regarding the development of biofuels (e. g., biogas, bioethanol and biodiesel) and their related technologies, which are still on trial (mainly regarding the bioethanol production), and must also analyze their sustainability from a social and economic standpoint. The paper discusses the use of biofuels for transport in the European setting, and shows that their sustainability may result in relevant negative social effects due mainly to the use of land for energy crops (e.g., change of food price and world food shortage).

Keywords: biodiesel, bioethanol, European policy, sustainable mobility.

\section{Análise geral do papel atual e futuro dos biocombustíveis nos transportes na União Europeia (UE)}

\section{RESUMO}

A produção de biocombustíveis é fortemente reconhecida em todo o mundo como uma fonte de energia renovável para reduzir a dependência do mercado instável do petróleo. Bioetanol, o principal biocombustível produzido no mundo, é largamente utilizado para a 
mobilidade no Brasil, e também nos EUA, mas com diferenças de sustentabilidade, porque no Brasil ele é produzido a partir de um subproduto da indústria de cana-de-açúcar, enquanto nos EUA é fabricado com culturas alimentares. Biogás e biodiesel estão crescendo rapidamente, mesmo que em um nível muito menor do que o bioetanol. A União Europeia (UE) observa este assunto com grande interesse e, há dois anos, adoptou uma ampla estratégia para reduzir em $60 \%$ as emissões de dióxido de carbono no setor de transporte, até o ano 2050. A fim de alcançar esse resultado, será necessária a transformação do atual sistema europeu de transportes. A ambiciosa meta implicará em medidas complexas, incluindo a limitação do uso de combustíveis fósseis em favor de combustíveis renováveis. Este programa abre várias possibilidades de desenvolvimento dos biocombustíveis (ou seja, biogás, bioetanol e biodiesel). Para concretizar este avanço, é preciso se desenvolver tecnologias de nova geração em fase de experimentação (principalmente para a produção de bioetanol a partir de resíduos florestais), bem como a análise da sustentabilidade econômica e social desta nova fonte de combustível. Este artigo trata da utilização de biocombustíveis nos transportes no cenário europeu e mostra que a produção de biocombustíveis pode aumentar efeitos sociais negativos relevantes, principalmente ligados ao uso da terra para culturas energéticas em vez de alimentos com efeitos sobre o preço de mercado e da escassez mundial de alimentos.

Palavras-chave: biodiesel, bioetanol, políticas europeias, mobilidade sustentável.

\section{INTRODUCTION}

\subsection{The world policy toward biofuels}

The term "biofuels" includes the following products derived from biomasses or sub-derived products: biogas, biodiesel, bioethanol, bio-methanol, bio-ethers (Bio DME - DiMethylEhter; bio-ETBE - EthylTerButylEther; bio-MTBE - MethylTerButylEther), synthetic biofuels, bio-hydrogen and vegetable oils. Considering the level of production, market interests are primarily focused on the first three (Morosini et al., 2012; Raboni et al., 2013).

As renewable energy sources, biofuels have several advantages:

1. Significant benefits in reducing $\mathrm{CO}_{2}$, micro- and macro-pollutants (e.g., particulate matter, PM) and emissions (FAO, 2008; Torretta et al., 2013);

2. Helping countries to increase their energy security creating a more stable energy market;

3. Development of a new economy associated with both energy crop cultivation and biofuels production.

For these reasons many countries promoted programs in favour of biofuels. The consequence has been a rapid growth of biofuel production in the last decade (US-EIA, 2014), even though since 2010 a decline due to the global economic crisis has appreciably reduced the energy demand. Also, social sustainability of biofuels influenced the trend because land exploitation for energy crops instead of food production threatens food availability.

The transport sector is the main biofuels consumer. Figure 1 shows biofuels' share of overall fuel consumption for road transport (WEC, 2014; EurObserv'ER, 2014; US-EIA, 2014).

Biofuels represent $3.3 \%$ of the total fuel used in road transport. This amount of biofuel is produced by less than $3 \%$ of all cultivated land on earth $\left(4.7 \times 10^{5} \mathrm{~km}^{2}\right)$. Asia and Pacific area have low shares of biofuel (below 1\%), while good performances are demonstrated by Brazil, which stands out for its effective policy towards renewable energies. Since the early 70's, Brazil has had a vast program in place for ethanol production from sugar cane, primarily for 
motor vehicles. In 2013, 52\% of the Brazilian cars were equipped with "flex" engines fueled with gasoline, ethanol or mixtures of both (Sindipeças and Abipeças, 2014).

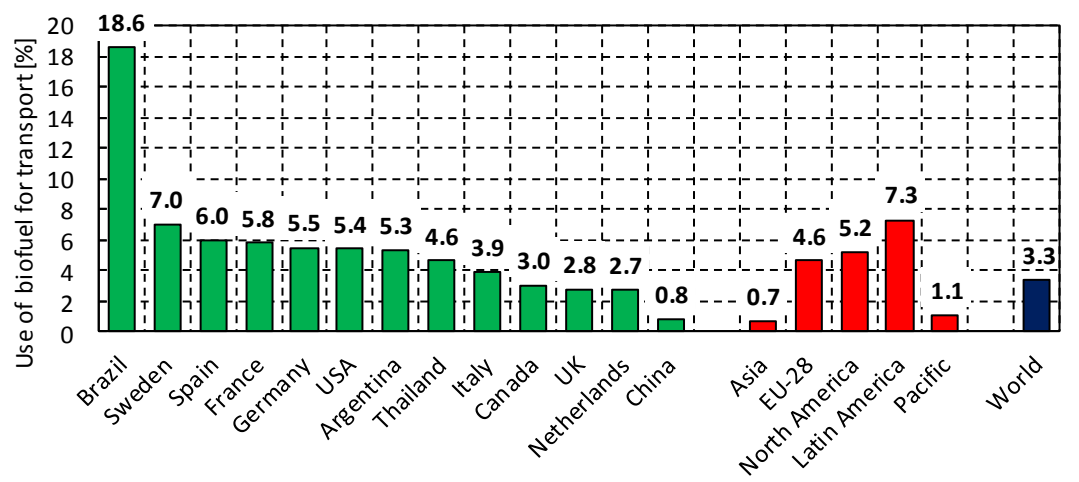

Figure 1. Share of biofuels for road transport (2011 data).

Brazilian energy policy has also included biodiesel. The production of biodiesel from vegetable oils (mainly from palm, castor and Jathropha curcas seeds) is actually under development, while great interest is focused on Used Cooking Oil - UCO (Torres et al., 2013).

Since 2000, the European Union (EU) has devoted great effort to promote biofuels, issuing several programmatic actions, such as (Raboni et al., 2013):

1. The "Green Paper" (European Commission, 2000), which introduced the target of replacing $20 \%$ of energy derived from fossil fuels with renewable energies by 2020 ;

2. The Directive 2003/30/EC (European Parliament, 2003), which stated targets for biofuels use: $2 \%$ by 2005 and $5.75 \%$ by 2010 ;

3. The package of proposals which established a common European energy policy (European Commission, 2007). It states that by 2020 biofuels will replace at least $10 \%$ of fossil fuels;

4. The Directive 2009/28/CE regarding the promotion of energy from renewable sources (European Parliament, 2009), which defines mandatory targets for the Member States in order to allow the sector to grow more efficiently. The Renewable Energy Directive (RED) aims at achieving 20\% of renewable energy consumption in the whole EU by 2020 . Concerning the transport sector, the share of renewable energy sources should be at least $10 \%$;

5. The "Transport 2050" plan (European Commission, 2011), aiming at creating a European common space able to improve the mobility of people and goods, as well as reducing $60 \%$ of $\mathrm{CO}_{2}$ emissions in transport by 2050. In order to achieve this target, the plan provides for a deep transformation of the current European transportation system through a complex plan based on the following main points:

5.1 Urban transport: halving the number of cars that relies upon traditional fuels (diesel and gasoline) in cities by 2030 and excluding them by 2050;

5.2 Intercity travels: by 2050 , the majority of passengers' mid-range transport (over $300 \mathrm{~km}$ ) will take place by train. Thirty percent and $50 \%$ of freight transport by road will switch to other methods of transport such as rail and inland waterways by 2030 and 2050, respectively; 
5.3 Long range trips and intercontinental freight transport: the use of low $\mathrm{CO}_{2}$ emission fuels in aviation sector will reach $40 \%$ of total fuel consumption by 2050. By the same date, $40 \%$ of the maritime navigation $\mathrm{CO}_{2}$ emission will be cut.

The EU strongly needs to reduce its oil dependence, which nowadays amounts to more

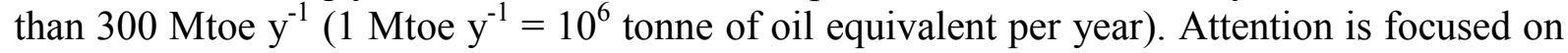
the transport system, traditionally based on oil and responsible for more than $21 \%$ of overall greenhouse gas (GHG) emissions, with an increasing trend higher than other economic sectors. Actually, the EU policy is fundamentally focused on biofuels. The EU estimated a $14 \%$ share of biofuels in 2020 , which could reduce GHGs emissions $(101 \div 103$ Mtonne $\left.\mathrm{CO}_{2} \mathrm{e}^{-1}\right)$.

The Directives 2001/77/EC (European Parliament, 2001) and 2003/30/EC established different national targets for renewable energy production and biofuel for transport consumption in order to reach a share of $21 \%$ and $5.75 \%$, respectively, by 2010 . Neither of the goals was reached (European Commission, 2011b). Therefore, in this decade the EU will work to double the production of renewable energies dedicated to transport in order to achieve the target of $10 \%$, as demonstrated by the member states' plans (Figure 2).

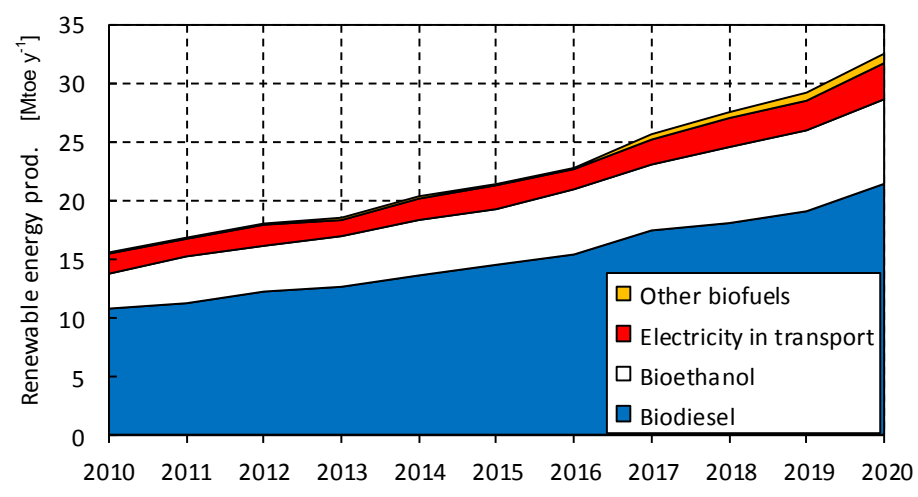

Figure 2. Growth of renewable energies for transport in the EU (EC, 2011b).

Biodiesel is and will be the main biofuel source ( $66 \%$ of the total renewable energy for transport in 2020), followed by bioethanol. The other biofuels (e.g. bio-hydrogen) have and will have almost no contribution. The EU will have to invest in the field of advanced technologies related to renewable energies in order to reach the 2020 targets both in terms of cost-effectiveness and environmental sustainability.

This paper analyzes the role of biofuel (biogas, biodiesel and bioethanol, in particular) in the EU transport sector, comparing the results with global production and considering the social and environmental sustainability of the policies.

\section{MATERIALS AND METHODS}

The research methodology was as follows:

1. Bibliographic research on the production and use of biogas, bioethanol and biodiesel in the European member states and comparison with world production;

2. Collection of documents concerning legislation and strategies issued by the EU and its member states aimed at encouraging and promoting biofuel production, conversion into energy and use in transport; 
3. Collection and analysis of technical and economic data regarding 285 European plants (biogas: 225; biodiesel: 55; bioethanol: 5);

4. Collection of documents regarding environmental sustainability of biofuels.

The results presented in this paper are a concise part of the more complex work produced by the research team.

\section{RESULTS AND DISCUSSION}

\subsection{Biofuels production}

\subsubsection{Biogas and biomethane}

Biogas production comes mainly from Municipal Solid Waste (MSW) landfills, sewage sludge anaerobic digestion, MSW Organic Fraction (MSWOF) and the agro-zootechnical waste biogasification plants (Urbini and Torretta, 2008; Martinez et al., 2014). Figure 3 shows global biogas production in 2012 and its trend till 2022.

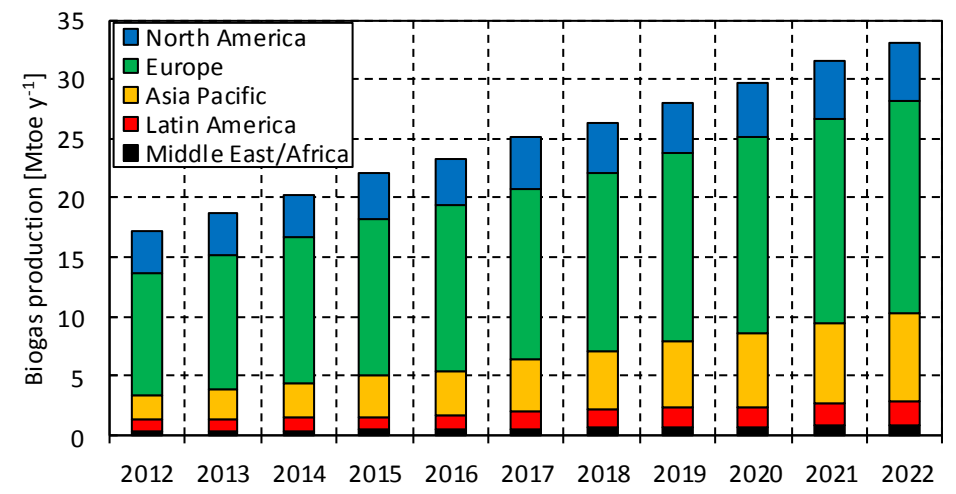

Figure 3. Global biogas production in 2012 and its trend to 2022 (Raboni and Urbini, 2014).

Europe is the major producing continent (about 12 Mtoe $\mathrm{y}^{-1}$ ): $53 \%$ is supplied by Germany. United Kingdom (1.8 $\mathrm{Mtoe}^{-1}$ ) is the second producer, followed by France $\left(1.2\right.$ Mtoe $\left.^{-1}\right)$ and Italy $\left(0.4\right.$ Mtoe $\left.^{-1}\right)$. Nevertheless, the biomethane contribution to European biofuels market is limited to $0.3 \%$. In Italy, France and even more in the UK, biogas production is strongly bound to old landfills. Germany proves to be the only country that promoted a confident and effective policy for the promotion of this renewable energy through the construction of numerous biogasification plants based on organic matrices (including energy crops). It should be noted that in 2012 this kind of biogas amounts to about $66 \%$ of all EU production. According to EU plans, the biogas production target in 2020 will raise to $15 \mathrm{Mtoe}^{-1}$, with a corresponding electricity production of $56,400 \mathrm{GWh} \mathrm{y}^{-1}$.

In the EU, the conversion of biogas to energy is devoted almost entirely to electricity production, while the use in vehicles is still very limited. In fact, in only a few cases the biogas produced is converted into pure methane (Biomethane with a $\mathrm{CH}_{4}$ content higher than 95\%) and used as biofuel. The greatest use as Biomethane for transport is a concern of Central and Northern European countries (Switzerland and Sweden, in particular). In Sweden, the new biodigesters fed by organic matrices are equipped with systems able to upgrade the biogas into Biomethane for vehicles and the natural gas network. In this country, 4,000 light-duty vehicles as well as several fleets of vehicles for public transport fed by Biomethane or natural gas are currently circulating. In many Swedish cities, the use of methane for transport is favored by different forms of incentives (e.g., free parking, detaxation of 
Biomethane purchase, toll exemption, dedicated lanes for Biomethane taxies, financial support for the purchase of Biomethane fed vehicles) which created an excellent level of acceptance for such a biofuel (Van Foreest, 2012).

In the EU, these kind of solutions are still rather isolated; even in Italy, the majority of the biogas is converted into electricity in cogeneration plants, by virtue of relevant incentives allowed by the Italian Financial Act 2008, known as "Green certificates" (GSE, 2014).

\subsubsection{Liquid biofuels (biodiesel and bioethanol)}

Due to the marginal role of biomethane, it is possible to assert that the world biofuels market is currently dominated by biodiesel and, above all, bioethanol. Figure 4 shows the world and EU production of biodiesel and bioethanol during the period 2000-2012 (EurObserv'ER, 2014; Ren21, 2014; US-EIA, 2014).
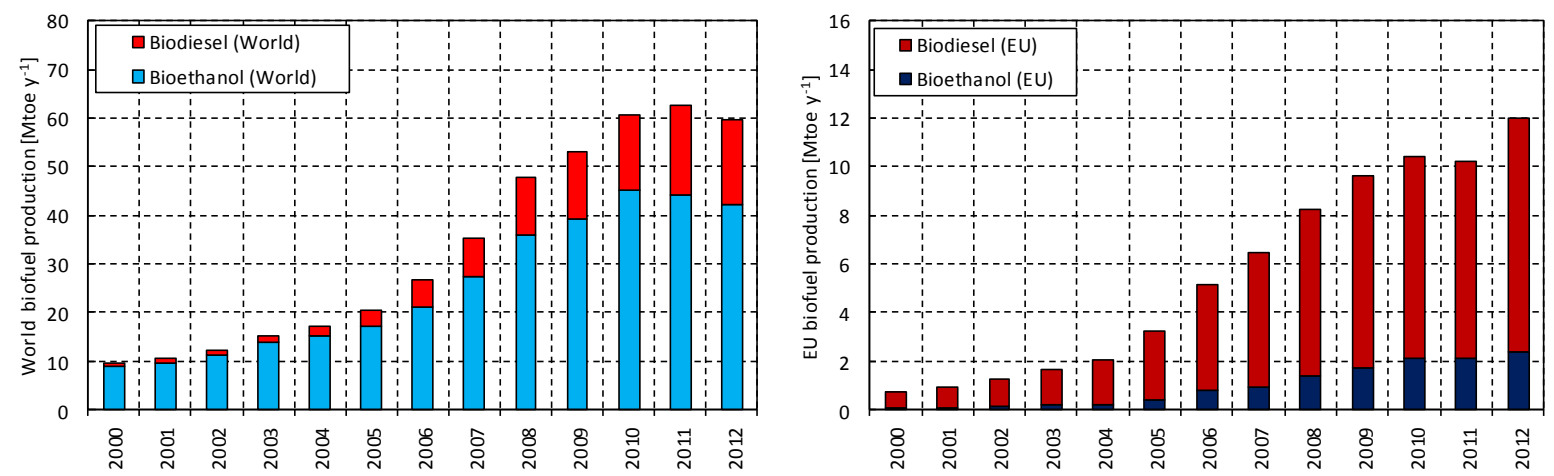

Figure 4. Biodiesel and bioethanol production trend in the World (left) and in the EU (right).

The 2012 global biodiesel and bioethanol production was about $60 \mathrm{Mtoe}^{-1}$; its growth in the last 9 years is notable even if in 2012 it suffered a slight decline (-4\%), mainly due to

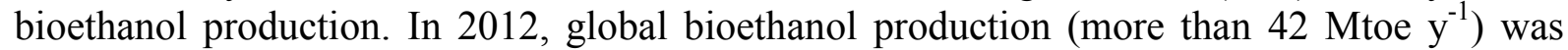
mainly concentrated in North and South America: Brazil and USA are responsible for about $90 \%$ of overall production, while the European share is around $6 \%$. Regarding biodiesel, the

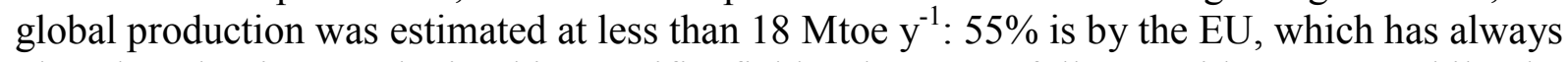
played a dominant role in this specific field. The USA follows with $16.7 \%$, while the remainder is distributed throughout several emerging countries (Brazil and Argentina, particularly). Table 1 lists detailed data concerning the most important European producers and consumers for transport (EurObserv'er, 2014).

Table 1. EU biofuel production and use for transport in $2012\left(\mathrm{ktoe}^{-1}\right)$.

\begin{tabular}{lccccc}
\hline Country & \multicolumn{2}{c}{ Bioethanol } & & \multicolumn{2}{c}{ Biodiesel } \\
\cline { 1 - 2 } \cline { 5 - 6 } & Production & $\begin{array}{c}\text { Use for } \\
\text { transport }\end{array}$ & & Production & $\begin{array}{c}\text { Use for } \\
\text { transport }\end{array}$ \\
\hline Germany & 387 & 403 & & 2,861 & 2,191 \\
France & 600 & 209 & & 1,910 & 2,268 \\
Spain & 191 & 101 & & 925 & 1,899 \\
Italy & 75 & 40 & & 706 & 1,264 \\
Poland & 106 & 77 & & 370 & 669 \\
Austria & 108 & 34 & & 289 & 390 \\
Other member states & 952 & 538 & & 2,509 & 2,980 \\
\hline Total & $\mathbf{2 , 4 1 8}$ & $\mathbf{1 , 4 0 1}$ & & $\mathbf{9 , 5 7 0}$ & $\mathbf{1 1 , 6 6 1}$ \\
\hline
\end{tabular}


EU bioethanol production was about $2.4 \mathrm{Mtoe}^{-1}$, with a remarkable contribution from France $(25 \%)$ and Germany $(16 \%)$ while imported bioethanol is less than 1 Mtoe $\mathrm{y}^{-1}$ (EurObserv'ER, 2014). The major biodiesel-producing countries are Germany (30\%), France $(20 \%)$ and Spain (10\%).

The reasons why Europe has favored biodiesel production in the past are both historical and economic. The most-used fuel in the EU is diesel. Moreover, the EU is also a net importer of mineral diesel and a gasoline exporter. Therefore the priority for the EU policy was the search for a valid substitute for mineral diesel. From the economic point of view, European bioethanol production relies on uncompetitive or unsuitable crops respective to the Brazilian one, which is based on sugar cane which has an energy productivity from four to seven times higher than wheat, corn and sugar beet. Moreover, Brazilian bioethanol production has great advantages in terms of sustainability because it is based mainly on molasses, the by-product of the sugar cane industry. Bioethanol offers a great support to the Brazilian program for energy sustainability, together with hydro-electricity. It is important to consider that a federal decree forbids the sale of gasoline unless it is mixed with $25 \%$ bioethanol (E25). The growing success of "flex" vehicles allowed bioethanol to overtake gasoline consumption in 2008 .

In 2012, the EU biofuels consumption reached 14.6 Mtoe $\mathrm{y}^{-1}$, including the modest contribution offered by biogas and straight vegetable oils, which are $0.9 \%$ of overall biofuels consumption. This value represents $4 \%$ of total energy consumption in the EU. Therefore, the $5.75 \%$ target for 2010, defined by Directive 2003/30/CE, still remains difficult to achieve.

Both biodiesel and bioethanol produced in the EU are almost completely used in blends with oil-derived fuels (gasoline and diesel); their development perspectives are sensitively bound with the increase of mixing quotas allowed in the different member states. In Germany, the overall incorporation rate (biodiesel and bioethanol) has been $6.25 \%$ since 2009. Italy and the UK are still far from the 2010 EU target (4.5\% and 3.9\%, respectively). France is the most progressive of all: $7.57 \%$ compared to $5.15 \%$ (the EU average target).

The European Commission, looking at 2020 target, believes that the real target for biofuels growth should be placed around 14\%. This means that the production of biofuels should increase to 43.1 Mtoe $^{-1}$ (27 Mtoe $\mathrm{y}^{-1}$ composed of biodiesel). This growth should be achieved respecting the principles of social and environmental sustainability.

\subsection{Biofuels social sustainability}

The social sustainability of biofuels production is strictly bound to the competition of arable lands for energy crops rather than food production. The EU acknowledges not having enough cropland to achieve the 2020 goal: the most realistic strategy takes into account the importation of $50 \%$ the amount needed from third countries (Commission of EC, 2007).

The analysis of data regarding the 2000-2010 food market showed that biofuel policies alone were responsible for the increase in the price of cereals and vegetable oils by $1-2 \%$ and $4 \%$, respectively (Ecofys et al., 2012). Other studies confirm the growth trend in the future (up to $5-7 \%$ and $15-16 \%$ in 2018 for wheat and vegetable oils, respectively). Such food-price growth will have a large impact mainly in low-income countries and could create social instability. Moreover, the need for large amounts of cropland to produce energy crops is increasing land-grabbing in developing countries, with negative socio-economic impacts on local communities (e.g. loss of access to land, water and other natural resources; Ecofys et al., 2012).

The EU is very sensible to such issues and reinforced RED with an agreement among its member states regarding the Indirect Land Use Change (ILUC). The new agreement will generate a clear and net GHGs saving without negatively impacting on biodiversity and land use because it strongly promotes the development and use of the $2^{\text {nd }}-3^{\text {rd }}$ generation biofuels, such as the bioethanol produced by lignocellulosic matrices and waste (Council of the EU, 
2014). In fact, the EU internal production of biofuels will come from (i) $7.6 \%$ of the total arable lands ( $2 \%$ in 2012) and (ii) new generation biofuel processes (7.5 Mtoe $\mathrm{y}^{-1}$ ). Pilot plants implementing such technologies are already working with mixtures of MSWOF and organic waste from orange industry (Valencia, Spain), straw (Salamanca, Spain), straw and ditch reed (Alessandria, Italy). Even in the USA, there are currently about ten plants running or under construction operating on various agricultural, forestry and MSW. Several other experiments are reported in Japan, Canada and other countries.

\subsection{Biofuels environmental sustainability}

Biofuels environmental sustainability can be examined considering several aspects. One of the most significant is net carbon emission, assessed by the means of the Life Cycle Analysis (LCA) technique. Biofuels aim to be carbon neutral, that is to say the carbon released during fuel use (e.g. combustion in power transport or electricity generation) is absorbed and balanced by new plant growth. Carbon neutral fuels do not increase atmospheric $\mathrm{CO}_{2}$ levels, helping to reduce the greenhouse effect. Actually, every biofuel has a net carbon emission considering the contribution of both the production (e.g. feedstock production; process technology) and the combustion processes. In the last years, a relevant improvement in biofuel production technologies decreased carbon emissions (UK-DfT, 2014a). Figure 5 shows the current biofuels carbon intensity statistics resulting from different feedstock and technology, compared to traditional fossil fuels (UK-DfT, 2014a).

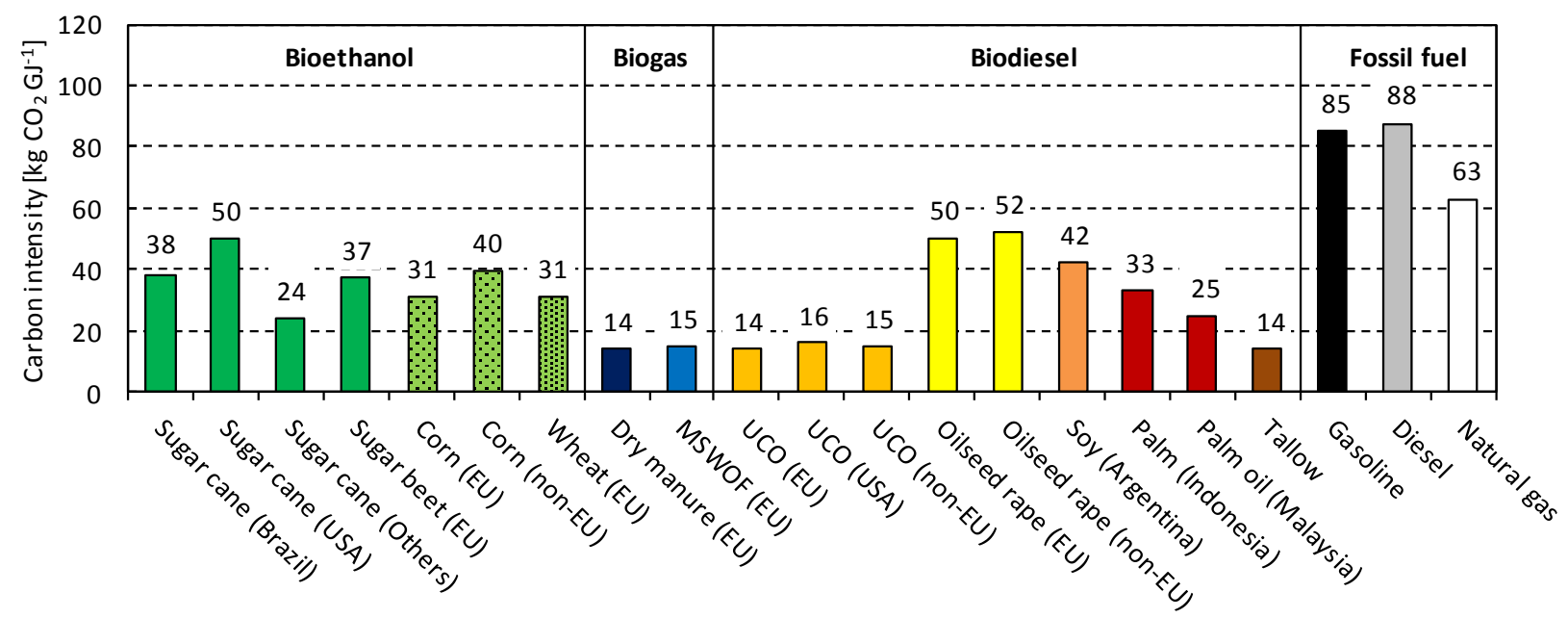

Figure 5. Carbon intensity of biofuels resulting from different feedstock and technology, compared to traditional fossil fuels.

Central American sugar cane, EU corn and wheat prove to be the most attractive source for the bioethanol production. On the contrary, it is noted that many other sources (e.g. USA sugar cane and corn; South Africa and Pakistan sugar cane; Ukraine wheat) do not allow substantial advantages respect to gasoline.

Considering biodiesel and biomethane, particularly interesting are the use of waste (e.g. UCO, tallow, MSWOF) and manure. On the other hand, biodiesel from oilseed rape and soy has a very high carbon intensity.

Another aspect of particular interest is represented by the emissions of pollutants derived from motor-vehicle combustion. Figure 6 shows the trend of emissions of truck fleets in relation to rising biodiesel-diesel blends. 


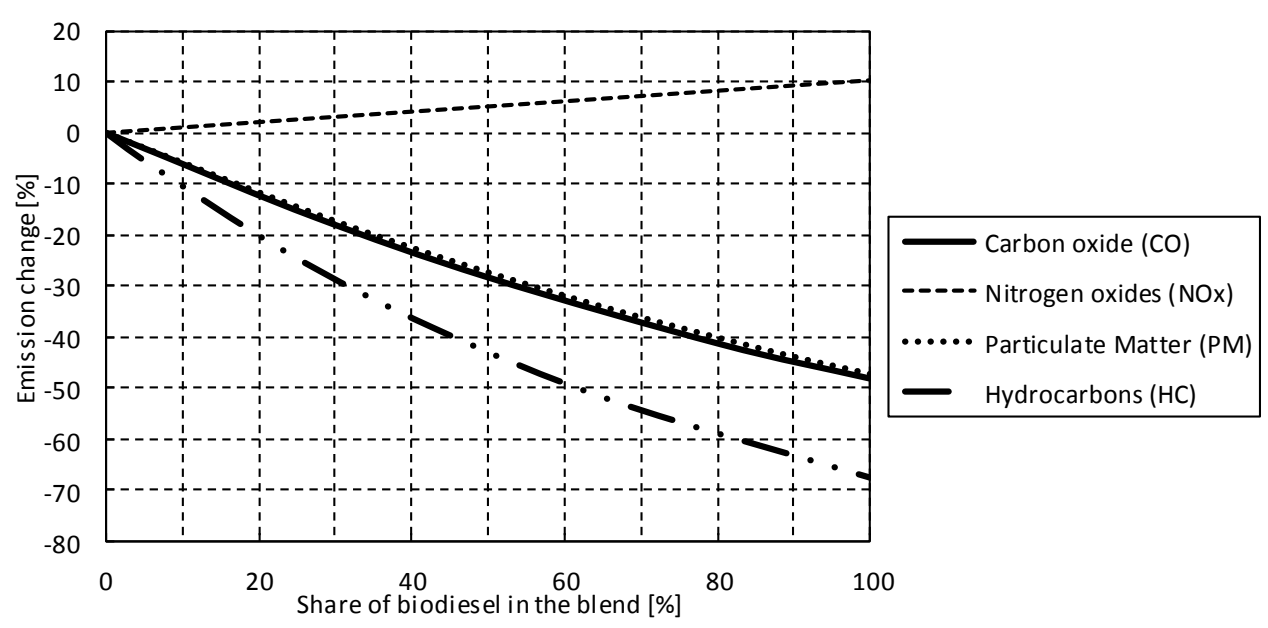

Figure 6. Macro-pollutants average emissions changes from the exhaust pipes of trucks fueled by rising rates of biodiesel (US-EPA, 2002).

The graph of Figure 6 clearly illustrates the following:

1. The complex of macro-pollutants emissions is reduced progressively moving from mineral diesel toward biodiesel blends, up to pure biodiesel (B100). PM-CO and hydrocarbon $(\mathrm{HC})$ reductions reach values of about $50 \%$ and $70 \%$, respectively;

2. A slight NOx increase occurs, up to values of about $10 \%$ for B100.

No substantial variations have been highlighted in relation to engine age or type. PM, HC and $\mathrm{CO}$ reductions are certainly correlated to the better combustion of the methyl-ester compared to traditional diesel due to both the presence of oxygen in the molecule and the high Cetane Number $(\mathrm{CN})$. The NOx increase $(5 \div 20 \%$ depending on the authors) has not been unequivocally justified by scientists: there is a tendency to correlate the phenomenon with (i) the presence of oxygen in the molecule and (ii) the combustion conditions (e.g.: pressure, temperature, low injection delay). Another hypothesis is the greater viscosity of biodiesel with respect to mineral diesel. In terms of macro-pollutant emissions, biodiesel benefits SOx reduction due to the near absence of sulfur, while significant concentrations of this compound characterize mineral diesel. A US-EPA study involving a total of 11 organic compounds (e.g. Acetaldehyde, Acrolein, Benzene, 1,3-Butadiene, Ethylbenzene, Formaldehyde, n-Hexane, Naphthalene, Styrene, Toluene, Xylene) confirms that pure biodiesel reduces macro-pollutant emissions by about 16\% (US-EPA, 2002).

Regarding bioethanol and gasoline, most of the experiments were carried out with ethanol/gasoline mixtures and the results are often contradictory. However, most significant data show a NOx, $\mathrm{CO}$ and $\mathrm{HC}$ reduction when the ethanol quota is increased. In an experiment in which 85\% bioethanol (E85) was compared with pure gasoline, emissions were reduced by $6 \%, 27 \%$ and $49 \%$ for NOx, CO and $\mathrm{HC}$, respectively (Avella, 2009).

An advantage stated for bioethanol is that the unburned emissions contribute significantly less to the formation of ozone, compared to organic compounds present in the gasoline exhaust emissions. In addition, the very low sulfur content of bioethanol produces virtually no sulfur dioxide $\left(\mathrm{SO}_{2}\right)$ emissions and improves the efficiency of catalytic emission control (UK-DfT, 2014b). However, while some of the most toxic pollutants (e.g. benzene, 1, 3-butadiene, toluene, xylene) decrease when using bioethanol, others (e.g. formaldehyde, acetaldehyde, peroxyacetyl nitrate) increase. For this aspect alone, there is a strong need for an in-depth human health and risk exposure assessment (Urbini and Stella, 2007; UK-DfT, 2014b). 


\section{CONCLUSIONS}

The biofuels future production and use in transport will be much diversified in different regions of the world. Countries which made important progress in the field of bioethanol (e.g. Brazil) have relevant margins for further growth because they have vast uncultivated areas and enjoy favourable climatic conditions for energy crops. Similar developments could affect other regions, including parts of Eastern Asia as well as Central and Southern Africa. Unfortunately, Europe does not enjoy the same favorable conditions. Nevertheless, the EU demonstrated a high sensibility to health and environmental protection upon issuing the "Transport 2050" plan, which aims at very ambitious targets in terms of sustainable mobility to be achieved by 2050. Consequently, biofuels (biodiesel, bioethanol and its derivatives, in particular) will play a significant role in energy policy. The contribution of biomethane will continue to be very marginal, except in few localities (e.g. Sweden).

The estimated growth of biodiesel and the bioethanol will present two fundamental issues:

1. The limited willingness of the EU to produce bioethanol for transport;

2. The environmental and, moreover, social sustainability due to land use for energy crops rather than food.

In order to overcome these obstacles, it will be necessary to import significant amounts of bioethanol and vegetable oils suitable for biodiesel production. In addition, the EU plans to produce bioethanol from lignocellulosic residues. Only the results of the current experiments in this field will confirm the effectiveness and the economic convenience of such processes.

In order to achieve the biofuels growth targets, it is expected that incentives through concrete legislative support (e.g. adoption of incentives such as tax exemption; increase of blending quote with fossil fuels; benefits for production and purchase of dedicated/hybrid vehicles; facilitation in road circulation and parking) will be necessary. Therefore, in the near future biofuels could play a significant role in transportation and could effectively contribute, together with electric vehicles which are already increasing in medium to large cities, to the achievement of the EU "Transport 2050" plan targets, with a hopeful eye toward the promising development of hydrogen cars.

\section{ACKNOWLEDGEMENTS}

The results presented are part of: (i) a two-year research program funded by Regione Lombardia (Italy) concerning "Biodiesel project for the sustainable development - Production of energy and economic self-sufficiency of a small community - Bahia State, Brazil " carried out in collaboration with the Laboratory of energy and gas of UFBA - Federal University of Bahia, Brazil and FEP - Foundation of Polytechnic School of UFBA; (ii) a two-year research program funded by the Italian Government in the framework of the PRIN projects (Research Programme of Projects with a National Relevant Interest) concerning the status of biogas production and use in the European countries.

\section{REFERENCES}

AVELLA, F. Bioethanol as fuel for transport - Behaviour in engines and influence on pollutant emissions (in Italian). Technical report 200904183. Combustibles Experimental Station. Milan: [s.n.], 2009. 
COMMISSION OF THE EUROPEAN COMMUNITIES. Biofuels progress report - Report on the progress made in the use of biofuels and other renewable fuels in the Member States of the European Union. Brussels, 2007.

COUNCIL OF THE EUROPEAN UNION. Proposal on indirect land-use change: Council reaches agreement. Luxembourg, $13^{\text {th }}$ June 2014.

ECOFYS; FRAUNHOFER INSTITUTE; BECKER BÜTTNER HELD - BBH; ENERGY ECONOMICS GROUP - EEG; WINROCK INTERNATIONAL. Renewable energy progress and biofuels sustainability. Report for the EC ENER/Ci/463-2011-Lot2. Utrecht, The Netherlands, 2012.

EUROBSERV'ER. l'Observatorie des energies renouvelables database. Available in: http://www.eurobserv-er.org/. Access in August 2014.

EUROPEAN COMMISSION. A European strategy for sustainable, competitive and secure energy. Green paper of the European Commission. Brussels, Belgium, 2000.

EUROPEAN COMMISSION. An energy policy for Europe. Brussels, Belgium, 2007.

EUROPEAN COMMISSION. White Paper 2011 - Roadmap to a Single European Transport Area - Towards a competitive and resource efficient transport system. Brussels, Belgium, 2011a.

EUROPEAN COMMISSION. Recent progress in developing renewable energy sources and technical evaluation of the use of biofuels and other renewable fuels in transport in accordance with Article 3 of Directive 2001/77/EC and Article 4(2) of Directive 2003/30/EC. Brussels: Commission Staff Working Document, 2011b.

EUROPEAN PARLIAMENT. Directive 2001/77/EC on the promotion of electricity produced from renewable energy sources in the internal electricity market. Brussels, 2001.

EUROPEAN PARLIAMENT. Directive 2003/30/EC of the European Parliament and of the Council of 8 May 2003 on the promotion of the use of biofuels or other renewable fuels for transport. Brussels, 2003.

EUROPEAN PARLIAMENT. Directive 2009/28/EC on the promotion of the use of energy from renewable sources and amending and subsequently repealing Directives 2001/77/EC and 2003/30/EC. Brussels, 2009.

FOOD AND AGRICULTURE ORGANIZATION (FAO). The state of food and agriculture. Rome, 2008. 128 p.

GESTORE SERVIZI ENERGETICI - GSE. Green Certificates (GCs). Available in: www.gse.it/en/qualificationandcertificates/GreenCertificates/Pages/default.aspx. Access in August 2014.

MARTINEZ, S.; TORRETTA, V.; MINGUELA, J.; SIÑERIZ, F.; RABONI, M.; COPELLI, S. et al. Treatment of slaughterhouse wastewaters using anaerobic filters. Environ. Technol., v. 35, n. 3, p. 322-332, 2014. http://dx.doi.org/10.1080/09593330.2013.827729 
MOROSINI, C.; STELLA, S.; URBINI, G. Biofuels for the sustainable mobility: current and future role in Italy and in the EU. In: INTERNATIONAL SYMPOSIUM OF SANITARY AND ENVIRONMENTAL ENGINEERING SIDISA, 9., 26-29 June 2012, Milan, Italy. Proceedings... Milan, 2012.

RABONI, M.; TORRETTA, V.; URBINI, G. The future of biofuels for a sustainable mobility. In: WORLD SUSTAIN. FORUM, 3.; SCIFORUM ELECTRONIC CONFERENCE SERIES, 3., 1-30 November, 2013. Proceedings... http://dx.doi.org/doi:10.3390/wsf3-f009

RABONI, M.; URBINI, G. Production and use of biogas in Europe: a survey of current status and perspectives. Rev. Ambient. Água, Taubaté, v. 9, n. 2, p. 191-202, 2014. http://dx.doi.org/10.4136/ambi-agua. 1324

REN21 STEERING COMMITTEE. Renewables 2014 Global Status Report. Paris, 2014.

SINDICATO NACIONAL DAS INDUSTRIA DE COMPONENTES PARA VEÍCULOS AUTOOMOTORES - SINDIPEÇAS; ASSOCIAÇÃO BRASILEIRA DAS INDÚSTRIAS DE AUTOPEÇAS - ABIPEÇAS. Relatório da frota circulante de 2014. São Paulo, Available at:

http://automotivebusiness.anankecdn.net.br/pdf/pdf_171.pdf.

TORRES, E. A.; CERQUEIRA, G. S.; FERRER, T. M., QUINTELLA, C. M.; RABONI, M.; TORRETTA, V. et al. Recovery of different waste vegetable oils for biodiesel production: A pilot experience in Bahia State, Brazil. Waste Management, v. 33, n. 12, p. 2670-2674, 2013. http://dx.doi.org/10.1016/j.wasman.2013.07.030.

TORRETTA, V.; RABONI, M.; COPELLI, S.; RADA, E.C.; RAGAZZI, M.; IONESCU, G. et al. Application of strategies for particulate matter reduction in urban areas: an Italian case. UPB Sci. Bull. Series D, v. 75, n. 4, p. 221-228, 2013.

UNITED KIGDOM. Department for Transport (UK-DfT). Biofuel statistics. London, 2014a. Available in: https://www.gov.uk/government/collections/biofuels-statistics. Access in August 2014.

UNITED KIGDOM. Department for Transport (UK-DfT). Renewable Transport Fuels Obligation (RTFO) guidance. London, 2014b.

URBINI, G.; STELLA, S. Development perspectives for biodiesel: new EU strategies, technological trends, environmental effects (in Italian). Ingegneria Ambientale, v. 10/11, 2007.

URBINI, G.; TORRETTA, V. Anaerobic digestion and biogas recovery from MSWOF and other organic matrices (in Italian). PRIN-2006 final report. [S.1.]: [s.n.], November 2008.

UNITED STATES. Energy Information Administration (US-EIA). International energy statistics database. Available in: http://www.eia.gov/countries/data.cfm. Access in August 2014.

UNITED STATES. Environmental Protection Agency (US-EPA). A Comprehensive analysis of Biodiesel impacts on exhaust emissions. Report EPA420-P-02-001, 2002. Washington, DC, 2002.

VAN FOREEST, F. Perspectives for biogas in Europe. Report NG 70. Oxford: The Oxford Institute for Energy Studies, 2012. 54 p. 
WORLD ENERGY COUNCIL. ENERDATA. Energy efficiency indicators database. Available in: http://www.wec-indicators.enerdata.eu/. Access in August 2014. 